\title{
LANGUAGE AND THE COVID-19 PANDEMIC: TRANSLATION OF ENGLISH CORONAVIRUS-RELATED NEOLOGISMS INTO UKRAINIAN
}

\author{
МОВА Й ПАНДЕМІЯ СОVID-19: ОСОБЛИВОСТІ ПЕРЕКЛАДУ \\ АНГЛОМОВНИХ НЕОКОВІДИЗМІВ НА УКРАЇНСЫКУ МОВУ
}

\author{
Kobyakova I.K., \\ orcid.org/0000-0002-9505-2502 \\ PhD in Philology, Professor, \\ Head of the Department of Germanic Philology \\ Sumy State University \\ Kovalenko A.Ya., \\ orcid.org/0000-0003-0520-0039 \\ Master's student at the Faculty of Foreign Philology and Social Communications \\ Sumy State University
}

The COVID-19 pandemic has radically altered the global society resulting in the dramatic transition to new social patterns, rules, formats of work, etc. This study deals with the innovative linguistic content of the English COVID-19 discourse as a specific communicative-cognitive product reflecting the new tendencies in the neology domain. The study highlights the ways of translating English coronavirus-related neologisms into Ukrainian. In particular, it studies the potential and limitations of transcoding, descriptive translation, and modulation while rendering neolexemes and neophrasemes that emerged as a linguistic response to the COVID-19 outbreak. The study also analyses the verbalized peculiarities of language consciousness under dramatic conditions. Moreover, it focuses on morphological peculiarities, pragmatic intentions, and linguo-creative mechanisms of the innovative linguistic units. In particular, the productivity of telescopic models, verbalization of the call for joint activity during the pandemic, reconsidered categorization of activities, and the translation difficulties posed by these features are analysed.

The study aims at determining and analysing specific cases of the integrated coronavirus-related neologisms within the English COVID-19 discourse and reveals the specifics of their translation into Ukrainian. Moreover, the preconditions for treating the English COVID-19-discourse as a separate communicative-cognitive product, discursive manifestations of the ludic function exteriorized by puns, indirect call to unification, integrated metaphoric mechanisms, intra- and intercategory synonymy are determined. Special attention in the paper is drawn to the cases of transcoding, explication along with the lexicographic procedures by means of descriptive translation, and euphemization while translating certain coronavirus-related neologisms.

Key words: neologism, English COVID-19 discourse, ways of translation, neolexeme, neophraseme, pandemic.

Пандемія COVID-19 докорінно трансформувала життєдіяльність індивідів у глобальному масштабі, увінчавшись драматичною появою нових соціальних патернів, правил, форматів роботи тощо. У запропонованій розвідці розглядається лінгвістичний інноваційний матеріал англомовного дискурсу COVID-19, що постає як особливий комунікативно-когнітивний продукт і відображає нові тенденції в царині неології. Статтю присвячено пошуку й аналізу способів перекладу англомовних неоковідизмів на українську мову. Зокрема, детермінується потенціал й обмеження прийомів транскодування, дескриптивного перекладу та модуляції для репрезентації неолексем і неофразем, що виникли у відповідь на поширення захворюваності на COVID-19. У статті також визначаються тенденції вербалізованих настроїв мовної свідомості в драматичних умовах. Увага зосереджується на деяких морфологічних параметрах інноваційних лінгвістичних одиниць, прагматичних інтенціях та виявах лінгвокреативу, що екстеріоризуються за їхнього посередництва. Зокрема, аналізуються питання продуктивності телескопії, вербалізації заклику до спільних зусиль під час пандемії та оновленої категоризації певних видів діяльності, а також труднощі перекладу неологізмів, заснованих на таких особливостях.

У статті детермінуються й аналізуються конкретні фракти інтеграції неологізмів коронавірусної тематики у фрагменти англомовного дискурсу COVID-19 і розглядаються особливості їх перекладу на українську мову. Крім того, визначаються передумови виокремлення англомовного дискурсу COVID-19 як окремого комунікативно-когнітивного продукту, аналізуються дискурсивні прояви лудичної функції, екстеріоризованої за посередництва каламбуру, непрямого заклику до об'єднання, механізмів метафоризації, інтра- та інтеркатегорійної синонімії. Особливу увагу сфрокусовано на випадках транскодування, експлікації шляхом прийому описового перекладу за посередництва лексикографічних практик та евфемізації під час перекладу неоковідизмів.

Ключові слова: неологізм, англомовний дискурс COVID-19, шляхи перекладу, неолексема, неофразема, пандемія.

Introduction. With its global spread, the coronavirus pandemic (2020-till now) has not only transformed the lives of billions of people. Still, it has also provoked a considerable discussion around COVID19 in the communicative environment, particularly in cyberspace. The global community has never been so thoroughly informed about a social event as during the coronavirus pandemic. Thus, almost all spheres of human life are now operating in the social context of tackling the spread of COVID-19. 
Vocabulary replenishment is a historically inevitable process integral to language conformity with societal needs $[10$, p. 1]. The coronavirus pandemic context that requires compliance with new rules and a shift of priorities has established unique nomination needs. As a result, the pandemic has led to the increased number of new words, phrases, new meanings of previously existing words denoting topical objects and phenomena connected with the coronavirus outbreak and its post-events. Novelty, unusualness and exteriorization of previously unknown tendencies are the integral features of neologisms that are treated as the special layer of vocabulary with permanent content variability due to the progress in various spheres of society [14, p. 2]. The COVID-19-related neologisms are believed to reflect the current linguistic and social trends that ultimately require the translator to opt for and study the ways to render the innovative linguistic units in the target language. The increased attention to the impact of the coronavirus outbreak on linguistic processes determines the topicality of this study. Since the spread of the virus goes global, a study of the English COVID-19 discourse in the context of translation can be regarded as one of the necessary means of overcoming information gaps.

Analysis of recent research and publications. In the scientific discussion, the relevant research is primarily focused on the study of the word-formation processes within this thematic field of neologisms (O. Babeliuk, L. Didukh, K. Akut, A. Zrigue), interpretation of conceptual coronavirus-related metaphors (K. Krasnytska, N. Stepaniuk, A. Haddad, S. Montero-Martinez), of the linguistic aspect of mass media communication during the pandemic (T. Vesna, T. Teletska, I. Piller) as well as the sociolinguistic aspect of corona culture (E. Halytska, T. Chaiuk, G. Maldonaldo, A. Roig-Marin).

The main issues of neologisms translation are regarded in V. Karaban, V. Komisarov, N. Bilous, N. Novokhatska, A. Pohorila, O. Selivanova, O. Tymchuk, who contributed to the generalized ways of neologisms translation. The recent research by L. Diachuk and I. Dovzhenko considers the main ways of translating the coronavirus-related neologisms, new abbreviations, and terms in the English media texts into Ukrainian [3, p. 80]. L. Tereshchenko has offered several ways of English coronavirus-related puns translation into Ukrainian formed due to the linguo-creative efforts [8, p. 253].

As the English discourse around COVID-19 represents a new field of study, one may witness that the appropriate scientific discussion on the English coronavirus-related neologisms translation into
Ukrainian is at its developing stage. It is marked with the still relatively small but potentially growing number of the relevant translation studies due to the urgent need for information gaps elimination.

The purpose of this paper is to study the coronavirus-related neologisms as the main linguistic component of the English COVID-19 discourse in the context of their translation considering the communicative-cognitive specifics of the discourse under our study. The object of this paper is English neolexemes and new word combinations (neophrasemes) formed or reconsidered during the coronavirus pandemic. The subject of the paper is the translation difficulties of English coronavirus-related neologisms into Ukrainian and the ways to solve them.

Results and discussion. The response of language consciousness to the new social phenomenon of coronavirus, i. e. discussion on the issues connected with the spread of COVID-19, strategies for treatment and prevention, has led to the emergence of the appropriate discourse around COVID-19.

In modern linguistics, we may witness the attempts to consider the concept of discourse both in terms of its form and function. Studying the concept of discourse, the scholar F. Batsevych appeals to communication's pragmatic and thematic specifics. He treats discourse as an interactive phenomenon, a speech flow occurring within a specific communication channel and regulated by the participants' strategies and tactics [2, p. 138]. Besides the interpretation of discourse as a purposeful social action, i. e. extending traditional concepts (language and/ or text), the scholar A. Prykhodko believes discourse to denote both the process, that is to say, the exteriorization of the communicative-situational factors, and the result (a fixed text) [6, p. 51]. Given this approach to the essence of discourse, we assume that discourse is determined by dynamism and anthropocentrism as a manifestation of its dependence on the social context of the global community.

Determining the need to treat the COVID-19 discourse as a special product of language use, it is of crucial significance to identify the following reasons for the relevance of our approach: 1) increased number of coronavirus-related texts under the current pandemic tension; 2) boom of coronavirus-related neologisms arising as a result of new social rules in modern society; 3 ) emergence of new concepts (CORONAVIRUS, SELF-ISOLATION, LOCKDOWN, etc.); 4) increased number of the research on the impact of new realities on various spheres of life.

In the scientific discussion, the coronavirus-related messages are said to imply the involvement of nonverbal means (graphic and video elements), 
a high level of suggestion, and considerable use of linguistic innovations (neologisms) [1, p. 6], the representation of which in the target language may pose particular difficulties.

Such a range of features may be explained by the pragmatic requirements of the communicative situation. The primary senders' purpose within the COVID-19 discourse is the effective informational and psychological vaccination of the population, and ensuring citizens' (recipients') awareness of the quarantine rules global importance. Thus, linguistic means with a high level of influence may be integrated into the messages due to the extent of overcoming pandemic tension.

The COVID-19 pandemic has brought an entirely new approach to people's lives. It has inevitably been reflected in language with a considerable number of neologisms, in particular, in English. On the one hand, innovative linguistic units denote the new phenomena of the pandemic chronicles, i. e. they are supposed to fulfil a communicative function. On the other hand, they are supposed to be a relatively suggestive linguistic unit that meet the pragmatic goals of the discourse around COVID-19.

The term neologism denotes a new word or word combination or previously existing linguistic units that have acquired a new meaning due to various transformations in society $[10$, p. 5].

In the scientific discussion, the concept of neologism is mostly considered in the light of four concretizing criteria: 1) time (neologisms are treated as new units that have not existed before $[15, \mathrm{p} .11]$ ); 2) perception by the language community (neologisms are regarded as words perceived as new [14, p. 4]); 3) lexicographic criterion (neologisms are units new to a particular language, i. e. words that have not entered the general lexicon yet [11, p. 34]); 4) formal (neologism is a lexical unit with new form and/or meaning [7, p. 130]).

The following main ways of neologisms translation can be distinguished: transcoding, finding translation equivalents in the target language, descriptive translation, loan translation, and modulation [5, p. 13] with its advantages and limitations.

The lack of a direct lexical equivalent in the target language to represent an innovative linguistic unit determines the potential of transliteration (transfer of graphic form) and transcription (representation of sound form). However, significant differences in the phonetic systems of Ukrainian and English and the cacophony of certain lexical units formed using transliteration or transcription may determine the potential of other types of transcoding that are adaptive (adaptation of the source neologism to the phonetic or grammatical structure of the target language) and mixed transcoding.

However, a recipient of the translation may not comprehend the meaning of the neologism represented by transcoding. In this case, the foreign scholar A. Avagyan suggests explicating the neologism through descriptive translation or addition of certain elements [12]. Determining the efficiency to employ these techniques in the translation of coronavirus-related neologisms, in our opinion, one should be guided by the following factors: 1) whether a certain equivalent is fixed in the perception of the target audience in a transcoded form; 2) whether the neologism reproduced by means of transcoding in the target language is not cacophonic; 3 ) what background knowledge potential recipients of translation have.

The pragmatics of some coronavirus-related neologisms tends to decode the effect of unexpectedness in the verbalization of a particular concept to eliminate psychological stress, as mentioned above. In the course of the given study, we have identified a significant layer of neologisms formed by telescopic means, i. e. by means of amalgamation or fusion in which parts of two or more words are combined to create a new word. It can be explained by the immanent influence of such lexical units given their relatively creative structure.

In particular, we may emphasize the productivity of the following telescopic models:

1) Merging of the initial fragment (apocope) of one word and another word;

2) Merging of the apocope of a word and the final fragment (apheresis) of another one;

3) Combination of a non-shortened first word with the other apheresis.

To illustrate, in the following examples neolexeme covexit (Covid + exit) was formed by means of the first model appealing to the analogy of Brexit (British + exit) and Megxit (Megan + exit): (1) Eng. More and more experts discuss the strategy for covexit; (2) Eng. Treatment-based strategies can now be designed to "covexit" the crisis.

Given the linguistic reference (Eng. Brexit Ukr. Брекзит), we may justify the use of transcription in the Ukrainian translation of the noun covexit: (1) Ukr. Дедалі більше фахівиів обговорюють стратегію ковекзиту.

In addition, we believe that descriptive translation can be employed. Although devoid of brevity compared to transcoding, it implies the explication of a new concept without the precondition of individuals' in-depth background knowledge. For adequate reproduction of the neolexeme in Ukrainian using descriptive translation, let us study its defini- 
tion given in the Macmillan Dictionary: "Covexit is the process of gradually removing the restrictions on public life imposed by governments in response to the Coronavirus crisis" [13]. Given the definition, we can also represent it in Ukrainian as поступове послаблення карантинних обмежень.

In the case of translation of the verb to covexit, in our opinion, adaptive transcoding fails to accurately render the meaning of the neolexeme given the following factors:

1) Potential transcoded equivalent ковекзикувати is rather cacophonic, i. e. it does not correspond to the phonetic tendencies of Ukrainian;

2) The transcoded equivalent causes semantic dissonance because the lexeme екзикувати is quite artificial;

3) Potential recipients of the translation are expected to have the in-depth background knowledge to comprehend the concept.

Determining the influence of part of speech on the translation techniques potential while translating telescopic neolexemes, it is worth noting that when we reproduce the noun covexit, we may witness the parity of transcoding and descriptive translation and in the case of the appropriate verb the above-mentioned factors are to be considered. In the given context, the relevance of descriptive translation prevails (2) Ukr. Наразі можуть бути застосовані стратегіi в галузі медищини, щоб поступово подолати кризу, викликану коронавірусом.

The potential of transliteration is exteriorized in the translation of the following fragment of the COVID-19 discourse with the blend maskne (mask + acne) which denotes the consequences of wearing a mask formed by means of the third model: (3) Eng. How to Treat and Prevent Maskne; (3) Ukr. Лікування й попередження маскне.

Adaptive transcoding is used in the translation of the neologism lockstalgia (lockdown + nostalgia, model 2) which denotes the feeling of nostalgia for the isolation during the COVID-19 pandemic: (4) Eng. How to avoid "lockstalgia"; (4) Ukr. Як уникнути виникнення «локстальгії».

In our opinion, the fundamental need to employ descriptive translation does not arise due to the relative semantic comprehensibility of the telescopic component which carries the main semantic load and ultimately helps to interpret its meaning. In addition, the above-mentioned neologisms represent the social conceptual sphere of coronavirus, i. e. they denote phenomena that have arisen in the daily lives of individuals. It may determine their immanent comprehensibility in contrast to the concepts of the economic domain.
Neologisms twindemic (twin + pandemic, model 3) denoting the flu outbreak simultaneously with the coronavirus pandemic and infodemic (information + pandemic, model 2) which implies the boom of pandemic-related information were also formed by telescopic means: (5) Eng. Winter is coming. And so is the "twindemic"; (6) Eng. From pandemic to infodemic.

Contextual and pragmatic factors eliminate the need for descriptive translation of neologisms in the above-given discursive fragments. It may be justified to employ adaptive transcoding which can enable us to avoid the semantic overload of the utterance in the example (5) and to render the pragmatic conditionality (a reference to the similarity with the unit pandemic for the verbal influence on the recipient) in the given context: (5) Ukr. Зима йде, а з нею і твіндемія; (6) Ukr. Від пандемії до інфодемії.

Despite the fact that linguo-creative structure is a secondary feature of neologisms (compared to nonce words), in our study, we have identified cases when the ludic function of language manifests itself. To illustrate, pun as a means of language neologization is exteriorized in the lexeme quaranteam (quarantine + team, model 1) where the stylistic effect is created on the basis of phonemic substitution of the last syllable of the lexeme quarantine.

The correlation between the presupposition of the message and the recipients' general informational competence is an important aspect of successful communication [4, p. 115]. This precondition is integral but not sufficient for effective communication containing a pun as it requires the recipients to comprehend the unity of knowledge of the sound form and the meaning of the verbal sign. Thus, we resort to the transformation of modulation in the translation of the lexeme quaranteam and render it by non-ludic means as соціальний осередок ізоляції.

Representing a special layer among the neologic language processes, neophrasemes, i. e. innovative word combinations with idiomatic semantics, with their communicative-pragmatic peculiarities are of considerable interest in the perspective of translation studies.

The language system is said to be a self-regulated phenomenon that manifests itself in the tendency to overcome contradictions between the system and the situational requirements $[9$, p. 86]. The coronavirus pandemic has led to the opposition between "acceptable" and "unacceptable" phenomena. This approach requires a translator to employ the potential of euphemisms that can neutralize the negative connotation of the utterance. Thus, in the translation of the neophrasemes non-essential businesses and non-essential travel we avoid neg- 
ative dimensions of attitude by means of descriptive translation rendering them as сектори бізнесу, що забезпечують другорядні потреби громадян and поїздки другорядної необхідності respectively.

Moreover, we have found manifestations of intra-category synonymy within the English COVID-19 discourse, i. e. synonymous series of neophrasemes. To illustrate, the state call for staying at home is rendered with the following variations: stay-at-home orders, Safer at Home order, the shelter-at-home order.

Focusing on the current social situation, we believe that the relevant Ukrainian equivalent державні карантинні обмеження can render the meaning of the above-mentioned neophrasemes. Since in the given context it is a clearly defined order that is exteriorized using the definite article or capitalization, the integration of the adjective державний is pragmatically justified.

Another manifestation of the intra-category synonymy of neophrasemes in the COVID-19 discourse concerns the partnership between countries enabling people to travel without the need to undergo quarantine denoted with the neophrasemes travel bubble, corona corridor, quarantine-free corridor.

Comparing this synonymous series with the above-mentioned one, it should be noted that the discursive fragments from the tourism milestone of the COVID-19 discourse are characterized by heterogeneity of the connotative meaning. As a result, it leads to differentiation of the approaches to their translation. Thus, it may be efficient to render neophraseme travel bubble as альянс вільних подорожей, i. e. using modulation to exteriorize the unification during the pandemic. The neophrasemes quarantine-free corridor and corona corridor are devoid of expressiveness fulfilling mainly a nominative function. In the target language we render them as безпечний коридор sticking to the generalized meaning.

In the course of our study, we have found out that inter-category synonymy, i. e. synonymous relation between a certain neophraseme and a neolexeme, occurs less frequently than intra-category one. We should also emphasize that the exteriorized pragmatics to highlight common efforts, indirect call for the unification during the pandemic, the metaphoric mechanisms, and the expressiveness of innovations can be treated as integral features of the English COVID-19 discourse. To illustrate, these tendencies are exteriorized in the neophrasemes social bubble and pandemic pod synonymous with the previously mentioned neolexeme quaranteam.

To preserve the outlined pragmatic meaning, we employ the transformation of modulation: Eng. social bubble - Ukr. альянс ізоляиіï, Eng. pandemic pod Ukr. пандемічна рукавичка (based on the change of the metaphoric image).

Conclusions. The English COVID-19 discourse is based on the innovative linguistic content in response to the relatively unknown phenomena related to the spread of a new virus strain. The multifaceted nature of the language means involved, versatility of pragmatic components, and integrated mechanisms of semantic enrichment determine the translation specifics of English coronavirus-related neologisms. The results of our study bear evidence that under dramatic conditions language consciousness seeks to eliminate the negative dimensions of messages using the lexemes and phrasemes with positively verbalized concepts. It may be exteriorized by the creative structure (telescopic units) and metaphorical expression. Transcoding, descriptive translation, and modulation are of prominent productivity in the translation of the neologisms which exteriorize the above-described tendencies. The prospect of further research is the interpretation of new fragments within the English COVID-19 discourse considering the new tendencies and the ways of their reproduction in the target language. Moreover, the analysis of the ways to achieve communicative effectiveness within the English COVID-19 discourse is of promising signs.

\section{REFERENCES:}

1. Бабелюк О.А., Дідух Л.І. Способи творення неологізмів на позначення явищ COVID-19 в англомовному епідеміологічному дискурсі. Львівський фрілологічний часопис. 2020. № 7. С. 5-12.

2. Бацевич Ф.С. Основи комунікативної лінгвістики. Київ : Академія, 2004. 344 с.

3. Дячук Л.С., Довженко І.В. Особливості відтворення неологізмів, пов'язаних з COVID-19 в англійських медійних текстах українською мовою. Міжнародний фрілологічний часопис. 2021. Т. 12. № 1. С. 80-87.

4. Зимомря М.І., Зимомря І.М., Зимомря О.М. Переклад як модель лінгвістичної комунікації. Актуальні питання гуманітарних наук. 2014. Вип. 10. С. 113-118.

5. Карабан В.І. Переклад англійської наукової і технічної літератури. Граматичні труднощі, лексичні, термінологічні та жанровостилістичні проблеми : посібник. Вінниця : Нова книга, 2004. 576 с.

6. Приходько А.И. Когнитивные параметры изучения дискурса. Языковая личность и эфффективная коммуникация в современном поликультурном мире : материалы Международной научно-практической конференции, секция «Языкознание», Минск, 17-18 ноября, 2016 г. Минск : Издательский центр БГУ, 2016. С. 50-53. 
7. Сабан О.В. Функційно-прагматичні особливості відепонімних оказіоналізмів та неологізмів у сучасній англійській мові. Наукові записки Національного університету «Острозька академія». Серія «Філологія». Острог : Видавництво НаУОА, 2018. Т. 69. № 1. С. 129-132.

8. Терещенко Л.Я. Лінгвістична відповідь на COVID-19: мовна гра і труднощі перекладу. Соціальнополітичні, економічні та гуманітарні виміри європейської інтеграції України : зб. наук. пр. VIII Міжнар. наук.практ. конф. 2020. № 4. С. 253-261.

9. Швачко С.О. Модельовані та немодельовані паттерни словотвору в англомовному дискурсі. Філологічні трактати. 2012. T. 4. № 3. С. 84-88.

10. Akut K. Morphological Analysis of the Neologisms during the COVID-19 Pandemic. International Journal of English Language Studies (IJELS). 2020. Vol. 2. № 3. P. 1-7.

11.Algeo J. Fifty years among the new words: A dictionary of neologisms. Cambridge : Cambridge University Press, 2013. 267 p.

12. Avagyan A. Translation of English Neologisms. Terminology Coordination. European Parliament. 2015. URL: https:/termcoord.eu/2015/06/the-translation-of-english-neologisms (last accessed: 25.09.2021).

13. Covexit. Macmillan Dictionary. URL: https://www.macmillandictionary. com/dictionary/british/covexit (last accessed: 28.09.2021).

14. Janssen M. Orthographic Neologisms Selection Criteria and Semi-Automatic Detection. 2011. 13 p. URL: http://maarten.janssenweb.net/Papers/ neologisms.pdf (last accessed: 24.09.2021).

15. Schippan Th. Lexikologie der deutschen Gegenwartssprache. Tübingen : Max Niemeyer Verlag, 2002. 306 S.

УДК 81'255.4 (811.111)

DOI https://doi.org/10.32782/tps2663-4880/2021.19.2.21

\section{ОСОБЛИВОСТІ ПЕРЕКЛАДУ ФІНАНСОВИХ ТЕРМІНІВ} АНГЛІЙСЬКОЇ ГАЛУЗЕВОЇ ЛІТЕРАТУРИ

\section{TRANSLATION PECULIARITIES OF FINANCIAL TERMS IN ENGLISH PROFESSIONAL LITERATURE}

Крайняк Л.К., orcid.org/0000-0003-4713-9416 кандидат філологічних наук, дочент, завідувач кафедри іноземних мов та інформаційно-комунікаційних технологій Західноукраїнського національного університету

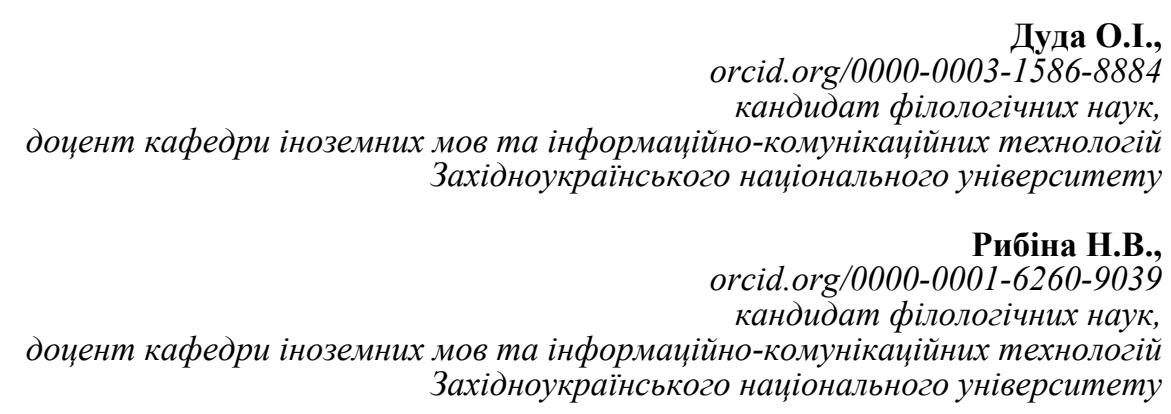

Запропонована стаття присвячена виявленню та аналізу особливостей перекладу фінансових термінів англійської галузевої літератури. На матеріалі корпусу текстів відповідної субмови авторами виокремлено фінансову терміносистему англійської мови та з використанням словників і спеціальних ресурсів виявлено значення ії термінів на основі їх функціонування в різножанрових текстах англійської літератури фінансової сфери. У статті здійснено спробу зіставити англійські та українські терміни, що формують відповідні фрінансові терміносистеми, на структурному і семантичному рівнях.

Особливу увагу авторами приділено виокремленню тих термінів англійської фрінансової субмови, переклад яких викликає певні труднощі (унаслідок існування декількох варіантних відповідностей, відсутності в українській мові термінів-еквівалентів, розбіжності між поняттями, що позначаються термінами-еквівалентами), та виявленню чинників, що зумовлюють проблеми перекладу вищезазначених термінів. 3'ясовано, що явище безеквівалентності виникає внаслідок відсутності або неідентифікації того чи іншого поняття, номінованого терміном іноземної мови, в терміносистемі мови перекладу. 